\title{
Journal of Sociology
}

Book Review: Eva Illouz, Why Love Hurts: A Sociological Explanation Renata Grossi

Journal of Sociology 2014 50: 623

DOI: $10.1177 / 1440783312465374$

The online version of this article can be found at: http://jos.sagepub.com/content/50/4/623.citation

Published by:

(SAGE

http://www.sagepublications.com

On behalf of:

\section{TASA}

The Australian Sociological Association

Additional services and information for Journal of Sociology can be found at:

Email Alerts: http://jos.sagepub.com/cgi/alerts

Subscriptions: http://jos.sagepub.com/subscriptions

Reprints: http://www.sagepub.com/journalsReprints.nav

Permissions: http://www.sagepub.com/journalsPermissions.nav

>> Version of Record - Nov 27, 2014

What is This? 
Eva Illouz (2012) Why Love Hurts: A Sociological Explanation. Polity Press, 293 Pp. ISBN- I3: 978-0-7456-6I52-0 (hardback)

\section{Reviewed by: Renata Grossi, Australian National University}

Anyone who has read Eva Illouz's groundbreaking book Consuming the Romantic Utopia: Love and the Cultural Contradictions of Capitalism (1997) knows what to expect from this latest book: a stimulating, thorough and provocative analysis which adds much to a concept which is 'the cultural core of modernity' (p. 11).

The stated aim of this book is to offer a much needed sociological explanation for a phenomenon which has more typically been left outside the discipline. Throughout the 20th century, romantic misery has been framed as a psychological discourse. This is problematic for a number of reasons. Since the rise of the courtly tradition of love, suffering has not only been an accepted part of the experience it has also been seen as a positive one (p. 127-8). In contrast, the modern medical/psychological discourse sees it as a 'disorganisation' of the body and of the mind, attributable to a flawed and weak self. The goal of the book then is to 'shift the angle of analysis' from 'dysfunctional childhoods' or 'insufficiently aware psyches', to the way that society and culture have come to 'structure modern selves and identities' (p. 4). Taking this approach, Illouz organises her argument around a number of key structures to examine the causes of romantic misery in late modernity.

The contemporary marriage market (chapter 2) is a 'self regulated market of encounters' (p. 41) where the competition has become more intense and more generalised, and where choice is, at least outwardly, governed by subjective factors such as personal taste, physical attractiveness and personality. How well one does on the marriage market is, therefore, linked to how well one does on the sexual market. This is a source of much of the romantic pain we feel.

The architecture of choice is dominated by the idea of freedom (chapter 3). Freedom has been the catchcry of both the marriage and the sexual markets, and while it 'must remain at the heart of our normative ideals' (p. 239), it can implicitly organise, and even legitimate inequality (p. 61). Both the marriage and the sexual market play out differently for men and women, and more generally disadvantage women in a number of ways.

Possibly the most important of these is the way in which commitment is sought and interpreted. Success in the sexual market enables men to compete with each other and affirm their sexual status (p. 73). In contrast, marriage and family are less sought after because they are no longer sites of male control and domination (p. 75). As such men want to stay in the sexual market for as long as possible. This is in contrast to women, whose time in the marriage market is of shorter duration. Career goals mean that women are entering later; the prevalence of sexiness and other strict criteria of beauty closely tied to age, and biological factors to do with reproduction, all impact upon this (p. 76-8). These factors, coupled with the phenomenon of commitment phobia, displayed mostly by men, have created a mismatch of goals and expectations whose control lies largely with men.

Concomitant with these changes is the increasing connection of love with a sense of self worth (chapter 4). Illouz argues that the power of love in modernity is in fact due to the fact that love 'provides a strong anchor for recognition, the perception and 
constitution of one's worth' (p. 120). However the idea of recognition is trumped by the idea of autonomy, and this again is a cause of both pain and inequality. Illouz argues that men, more than women, have not only 'internalised' the discourse of autonomy, but can more readily practise it (p. 136).

As a result of the discourse of psychology, the political ideals of fairness, the discourse of feminism and the overwhelming discourse of science and technology, love has also undergone a process of rationalisation. It has now become subject to rules of conduct, and aligned to well-being and happiness (chapter 5). And yet, the way in which it is mediated through our imaginations (more complexly constituted) and informationthick technologies such as the internet has created a gap between what is anticipated in our imagination and what is experienced in everyday life (chapter 6).

Thus, Illouz maps the social organisation of love and its pain in contemporary society. But Illouz does not want to do away with romantic pain. She does, however, want to see the development of alternative models of love that are more ethical, where 'masculinity and passionate commitment are not incompatible', and where 'the social experience[s] of women' are also clearly reflected (p. 247). Nor does she want to do away with the fundamentally modern ideas of freedom and autonomy, but rather to contribute to a project where 'we can better live these times' (p. 248).

Jennifer K.Wesely (2012) Being Female: the Continuum of Sexuality. Boulder, CO: Lynne Rienner Publishers, I 7 I pp., \$49.95 hbk, ISBN 978-I-58826-832-7.

\section{Reviewed by: Nicola Pitt, Monash University}

Despite being an incredibly important and pertinent issue, to understand what it means to be, and be constituted as, 'female' in the contemporary era is no easy undertaking. Jennifer K. Wesely's book represents one of many small yet not insignificant steps that are being made to further such an understanding. Her book analyses what is problematic about the sexualisation of women, which according to Wesely, has to do with how women are socialised, constituted as subjects, and in some instances, victimised and abused.

Drawing extensively from her prior, qualitative research into two groups in the United States which she characterises as being marginalised, vulnerable and at-risk - namely, female exotic dancers and women who are homeless - Wesely aims in this book to unpack the myriad ways in which sexualisation becomes chronically and systematically embedded into the lives and experiences of women from an early age. The processes of female sexualisation, Wesely argues, can dangerously affect and in some cases even thwart women's capacities to create and maintain healthy identity meanings and intimate relationships. Wesely also seeks in this book to engender the urgent need for serious institutional, educational and criminal justice reform, especially as it pertains to the gender-specific needs of women who are targeted and victimised differently, on account of culture's incessant sexualisation and frequent degradation of the female and her body.

One of the fundamental components of Wesely's text has to do with her conceptualisation of what she describes as the 'continuum of sexualization' and in all seven chapters of her book, Wesely attempts to illustrate and develop how this continuum shapes the 